\section{World Arthritis Day 2018 and National Mental IIIness Awareness Week}

World Arthritis Day* is October 12, 2018, and National Mental Illness Awareness Week ${ }^{\dagger}$ is October 7-13, 2018. World Arthritis Day encourages organizations and individuals to work toward increasing awareness about arthritis and other rheumatic conditions worldwide. National Mental Illness Awareness Week seeks to educate the public, combat stigma, and provide support to those affected by mental illness.

A report in this issue found that adults with arthritis had higher prevalences of symptoms of anxiety $(22.5 \%)$ and depression (12.1\%) compared with adults without arthritis (1). Community-delivered self-management educational programs, such as the Chronic Disease Self-Management Program, ${ }^{\$}$ can increase self-efficacy (confidence) and physical activity (e.g., walking), improve self-rated health, and reduce depression, fatigue, and pain (2). CDC works with national and state partners to disseminate these educational programs in communities.

\section{References}

1. Guglielmo D, Hootman JM, Boring MA, et al. Symptoms of anxiety and depression among adults with arthritis-United States, 2015-2017. MMWR Morb Mortal Wkly Rep 2018;67:1081-7.

2. Brady TJ, Murphy L, O'Colmain BJ, et al. A meta-analysis of health status, health behaviors, and healthcare utilization outcomes of the Chronic Disease Self-Management Program. Prev Chronic Dis 2013;10:120112. https://doi.org/10.5888/ $\operatorname{pcd} 10.120112$

\footnotetext{
*https://www.eular.org/what_we_do_dont_delay_connect_ today_2018.cfm.

${ }^{\dagger}$ https://www.nami.org/Get-Involved/Raise-Awareness/AwarenessEvents/Mental-Illness-Awareness-Week.

${ }^{\$}$ https://www.cdc.gov/arthritis/marketing-support/1-2-3-approach/ docs/pdf/provider_fact_sheet_cdsmp.pdf.
}

\section{Symptoms of Anxiety and Depression Among Adults with Arthritis - United States, 2015-2017}

\author{
Dana Guglielmo, $\mathrm{MPH}^{1,2}$; Jennifer M. Hootman, $\mathrm{PhD}^{1}$; \\ Michael A. Boring, $\mathrm{MS}^{1}$; Louise B. Murphy, $\mathrm{PhD}^{1}$; \\ Kristina A. Theis, $\mathrm{PhD}^{1}$; Janet B. Croft, $\mathrm{PhD}^{1}$; Kamil E. Barbour, $\mathrm{PhD}^{1}$; \\ Patricia P. Katz, $\mathrm{PhD}^{3}$; Charles G. Helmick, MD ${ }^{1}$
}

An estimated 54.4 million (22.7\%) U.S. adults have doctordiagnosed arthritis (1). A report in 2012 found that, among adults aged $\geq 45$ years with arthritis, approximately one third reported having anxiety or depression, with anxiety more common than depression (2). Studies examining mental health conditions in adults with arthritis have focused largely on depression, arthritis subtypes, and middle-aged and older adults, or have not been nationally representative (3). To

\section{INSIDE}

1088 Factors Contributing to Congenital Syphilis Cases New York City, 2010-2016

1094 Rates of Carpal Tunnel Syndrome in a State Workers' Compensation Information System, by Industry and Occupation - California, 2007-2014

1098 Outbreak of Salmonella Chailey Infections Linked To Precut Coconut Pieces - United States and Canada, 2017

1101 Notes from the Field: Multiple Cyclosporiasis Outbreaks - United States, 2018

1103 Notes from the Field: Lead Exposures Among Employees at a Bullet Manufacturing Company Missouri, 2017

1104 Notes from the Field: Spatially Associated Coincident and Noncoincident Cases of La Crosse Encephalitis — North Carolina, 2002-2017

1106 QuickStats

Continuing Education examination available at https://www.cdc.gov/mmwr/cme/conted_info.html\#weekly.

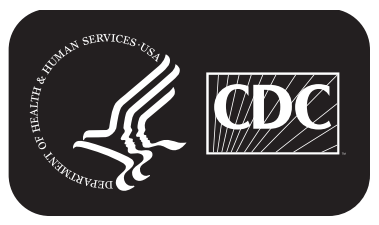

